\title{
IMPLEMENTATION OF DANISH SEINE PROHIBITION POLICY IN BATANG REGENCY OF CENTRAL JAVA PROVINCE, INDONESIA
}

\author{
Ravanelli Renata*, Student \\ Master's Program in Coastal Resource Management, Faculty of Fisheries and Marine \\ Science, University of Diponegoro, Indonesia \\ ORCID: 0000-0001-7181-0324
}

Fitri Aristi Dian Purnama, Mudzakir Abdul Kohar, Lecturers

Faculty of Fisheries and Marine Science, University of Diponegoro, Indonesia

ORCID: 0000-0002-4006-2391

*E-mail: renata.rav04@gmail.com

\begin{abstract}
Danish seine (Cantrang) is a controversial fishing gear caused by it considered as destructive fishing and has a low level of selectivity. A policy regulation on the prohibition of using Cantrang as fishing gear in Indonesia has been issued through the Ministry of Marine Affairs and Fisheries Number 2 of 2015 with the aim of preserving demersal fish resources especially in the Fisheries Management Area of the Republic of Indonesia (WPP-RI) 712. However, this policy has created opposition from Cantrang fishermen due to the economic impact, causing fishermen lost their only source of livelihood. This study aims to analyze the policy implementation factors that influence the implementation of the Cantrang prohibition policy. This study used a descriptive method with a qualitative approach with policy outputs and policy outcomes as indicators. Based on the results, outputs indicators and outcomes indicators in the implementation of the Cantrang prohibition policy was not achieved, especially the long-term outcome that became the policy objectives, which are to maintain the sustainability of demersal fish resources, to preserve coral reefs ecosystem and to manage illegal fishing activities for using non-environmentally friendly fishing gear are failed to be implemented. Factors that influence the failure of the Cantrang prohibition policy implementation are government's inconsistencies, disposition of fishermen as the policy target, and lack of financial support towards fishing gear replacement.
\end{abstract}

\section{KEY WORDS}

Policy implementation, policy outputs, policy outcomes, Cantrang, fisheries, marine affairs.

Batang Regency is one of district in Central Java Province which is part of the North Coast of Java with 10,933 people working as fishermen. Cantrang is used as the dominant fishing gear used by fishermen in Batang Regency (Ermawati \& Zuliyati, 2015). Cantrang or also known as boat seine is a fishing gear that has been used for generations and classified as a seine net (Boopendranath, 2012). Cantrang is made of net material resembling a large bag, cone-shaped and its getting smaller in the back of the net. The average mesh size is 2 inches to 4 inches. Cantrang divided in parts as wings, body and pocket (Purwangka et al., 2018). The bag design is used to increase the success of fishing for demersal fish as the main target (Sasmita et al., 2013). The target fish of Cantrang in general are Purple-spotted bigeye fish (Priacanthus tayenus), Sulphur goatfish (Upeneus sulphureus), Whipfin mojorra fish (Geres punctuatus) and Goldband goatfish (Upenus mullocensin) (Salim \& Suwardi, 2016).

Cantrang operation method is sweep the entire bottom of the waters (towing) with an area that can reach 292 hectares (Artati, 2018). The towing operation in Cantrang is threatening the coral reef ecosystem. According to Hadi et al., (2019), from 1,153 corals in Indonesia, the status of coral reefs in Indonesia is $33.82 \%$ poor, $37.38 \%$ moderate, $6.42 \%$ moderate and $6.42 \%$ very good. In addition, the shape of Cantrang which resembles a 
diamond allows Cantrang to be able to catch fish of various sizes, including juvenile fish. Although Cantrang does not operated in coral reef areas, the towing operation in Cantrang can sweep away small groups of live corals on the water bed, especially for Cantrang that have been modified with mess size smaller than 2 inches, thus it can threaten the sustainability of aquatic resources and ecosystems (Kartika, 2017; Artati, 2018).

Cantrang considered as a destructive fishing gear and is not environmentally friendly. As the impact of the destructive nature of the cantrang, the government made a policy to prohibit the use of the Cantrang as issued in the Regulation of the Minister of Marine Affairs and Fisheries Number: 2 / PERMEN-KP / 2015 concerning the Prohibition of Using Trawls and Seine Nets in the Fisheries Management Area of the Republic of Indonesia (WPP-RI). Fishing with Cantrang is included in illegal fishing, which violates Indonesia Law (UndangUndang) Number 45 of 2009 concerning Fisheries, which in Article 9 paragraph (1) everyone is prohibited from owning, controlling, carrying and/or using fishing gear and/or fishing aid that disturbs and destroys the sustainability of fish resources in the Fisheries Management Area of the Republic of Indonesia (WPP-RI); and paragraph (2) all provisions regarding fishing gear and/or fishing aids that disturb and damage the sustainability of fish resources as referred to in paragraph (1) are regulated in the Regulation of the Minister of Marine Affairs and Fisheries (Arisandi, 2016).

The purpose of the issuance of the regulation of the Ministry of Marine Affairs and Fisheries Number: 2 / PERMEN-KP / 2015 as the Cantrang prohibition policy is to maintain the sustainability of fishery resources and coral reef ecosystems. Exploitation of demersal fish resources has been carried out since 1978 and continued for four years before the Cantrang prohibition policy was issued, which are from 2011 to 2015 , as evidenced by a decrease in the sustainable potential by an average of $12.1 \%$ per year (Badrudin et al., 2011; Ma'mun et al., 2018). However, in terms of the policy implementation, this policy has resulted in conflict among fishermen in the North Coast of Java, especially in Batang regency. The conflict that occurred was hundreds of fishermen staging demonstrations to reject the stipulation of the Ministry of Marine Affairs and Fisheries Number: 2 / PERMEN-KP / 2015. Fishermen think that this policy will have an impact on the loss of fishermen's income sources, which will cause mass unemployment in Batang Regency. The conflict that occurred was caused by the lack of firmness from the government in implementing policy. The Cantrang prohibition policy purposes to protect the sustainability of demersal fish and coral reef resources has become ineffective.

The complexity of the policy on the prohibition of Cantrang in terms of marine resources, fishermen's social condition and government inconsistencies causes the results of this research can be used as study regarding the implementation of the policy on the prohibition of Cantrang in Batang Regency. Policy implementation is considered to be the main stage that largely determines the policy process. Without effective policy implementation, the Cantrang prohibition policy will be in vain (Mubarok et al., 2020).

\section{METHODS OF RESEARCH}

This study was conducted during March - April 2020 in Fishing Port (PPP) of Klidang Lor, Batang Regency, Central Java Province, as PPP Klidang Lor is the only fishing base for Cantrang vessels in Batang Regency.

This study used a descriptive method with a qualitative approach. Qualitative approach is used to describe the fishermen's response to the role of the government in implementing the Cantrang prohibition policy. Data collection techniques are through observation, direct interview with fishermen, and literature studies related to the policy of the implementation of the Ministry of Marine Affairs and Fisheries Number: 2 / PERMEN-KP / 2015. Interviews were conducted based on questionnaire. The questionnaire contains questions regarding matters related to the implementation of Cantrang prohibition policy, such as the frequency of policy socialization, the frequency of socialization regarding the importance of preserving demersal fish resources, whether or not deviations from alternative assistance and fishermen's perceptions of the appropriateness of alternative assistance offered by the 
government. The data was obtained through interviews presented by the percentage of each answer to the question asked as primary data and data processing of Cantrang catches productions from Marine Fisheries and Livestock Service (Dislutkannak) of Batang Regency as secondary data.

The sampling method used was purposive sampling. According to Sugiyono (2017), the purposive sampling method is used based on criteria that can support the results of the study. Respondents in this study are 33 captains of Cantrang vessels in Batang Regency. Captains were used as respondents as the first recipients along with vessels owners and the representative of the fishermen that received policy socialization held by the local government. The total population of Cantrang vessels in Batang Regency is 325 vessels. Based on the study method used, a sample size of $10 \%$ was taken from the total population, thus 33 captains were used as the sample by consideration one captain is leading one vessel (Mahmud, 2011).

Study indicator. The assessment is an important thing to do with indicators as a measuring tool (Cole \& Partson, 2006; Rachman, 2014). The measurement of policy implementation is used as a justification for assessing the success of the failure of policy when it is implemented (Rachman, 2014). Policy outputs and policy outcomes are used as the indicators of the study. According to Poister (2003), outputs represent what a policy does, whereas outcomes are the results of the policy itself. Policy outputs, as the name implies, is the output of policy and is used to measure the quality of that output. According to Ripley (1985), the policy outputs indicator is measured through several aspects, which are scope, bias, access, frequency, service delivery, accountability, and program suitability according to the needs (Table 1) (Purwanto \& Sulistyastuti, 2012).

Table 1 - Policy output indicators

\begin{tabular}{|c|c|c|}
\hline Number & Indicators & Description \\
\hline 1. & Scope & $\begin{array}{l}\text { This indicator is used to measure how many target groups can be reached by } \\
\text { the implemented policy }\end{array}$ \\
\hline 2. & Bias & $\begin{array}{l}\text { This indicator is used to assess whether there are groups outside the target } \\
\text { group who receive assistance from those that have been designed from the } \\
\text { policy }\end{array}$ \\
\hline 3. & Access & $\begin{array}{l}\text { This indicator is used to assess how easily the policy program is reached by } \\
\text { the target policy group. In addition, it is used to assess how easily the target } \\
\text { group can submit complaints and aspirations related to policies }\end{array}$ \\
\hline 4. & Frequency & $\begin{array}{l}\text { This indicator is used to determine how often the frequency of policy } \\
\text { socialization and assistance received in policy implementation. The higher the } \\
\text { frequency level is, the better policy was being implemented. }\end{array}$ \\
\hline 5. & Service delivery & $\begin{array}{l}\text { This indicator is used to assess whether the policy implementation is carried } \\
\text { out at the right time. }\end{array}$ \\
\hline 6. & Accountability & $\begin{array}{l}\text { This indicator is used to assess what actions the policy implementer has taken } \\
\text { in implementing the policy }\end{array}$ \\
\hline 7. & $\begin{array}{l}\text { Program's suitability } \\
\text { with people needs }\end{array}$ & $\begin{array}{l}\text { This indicator is used to assess whether the policy program is in accordance } \\
\text { with what the community needs }\end{array}$ \\
\hline
\end{tabular}

Source: Purwanto \& Sulistyastuti, (2012).

After the performance of the policy output is measured carefully, there will be an impact resulting on fishermen as the policy target. Policy Outcomes indicators are used to measure the results of policy implementation and assess whether there are changes to society after the policy is implemented (Schuman, 2016). Policy Outcome indicators are measured in three dimensions of time, namely initial outcome as short-term results, intermediate outcomes as medium-term results and long-term outcomes (Purwanto \& Sulistyastuti, 2012).

The performance of policy implementation is also influenced by several factors. Several experts put forward the factors that influence policy implementation, including Goggin and Edward III (Mubarok et al., 2020). According to Goggin et al., (1990), the factors that influence policy implementation are resources, public involvement and policy format consisting of policy clarity, policy consistency, frequency in delivering policies, and reputation of policy actors or local governments. Meanwhile, according to Edward III (2014), the factors 
that influence policy implementation are merged into the policy format, resources and the disposition of the government towards the policy as the implementers. Based on the opinion of the experts, the factors that influence policy implementation are merged into the policy format, resources and the disposition of policy implementers and policy targets.

\section{RESULTS OF STUDY}

Policy Outputs. Not all policy output indicators will be used, but only indicators that are considered relevant to the study, which are frequency, bias and program suitability with people needs.

The frequency indicators are used to assess how often the government does the socialization of the Cantrang prohibition policy. Policy socialization is an important step in policy implementation (Herdiana, 2008). The aim of policy socialization is to make sure the policy purposes and substances of the Ministry of Marine Affairs and Fisheries Number: 2 / PERMEN-KP / 2015 are well known by various related parties or named as stakeholders, including Cantrang fishermen as the policy target. Socialization is a foundation in the formation of knowledge and understanding for the fishermen towards the policy. Responses from the fishermen show that the socialization of Cantrang prohibition policy is often carried out in Batang Regency (Figure 1).

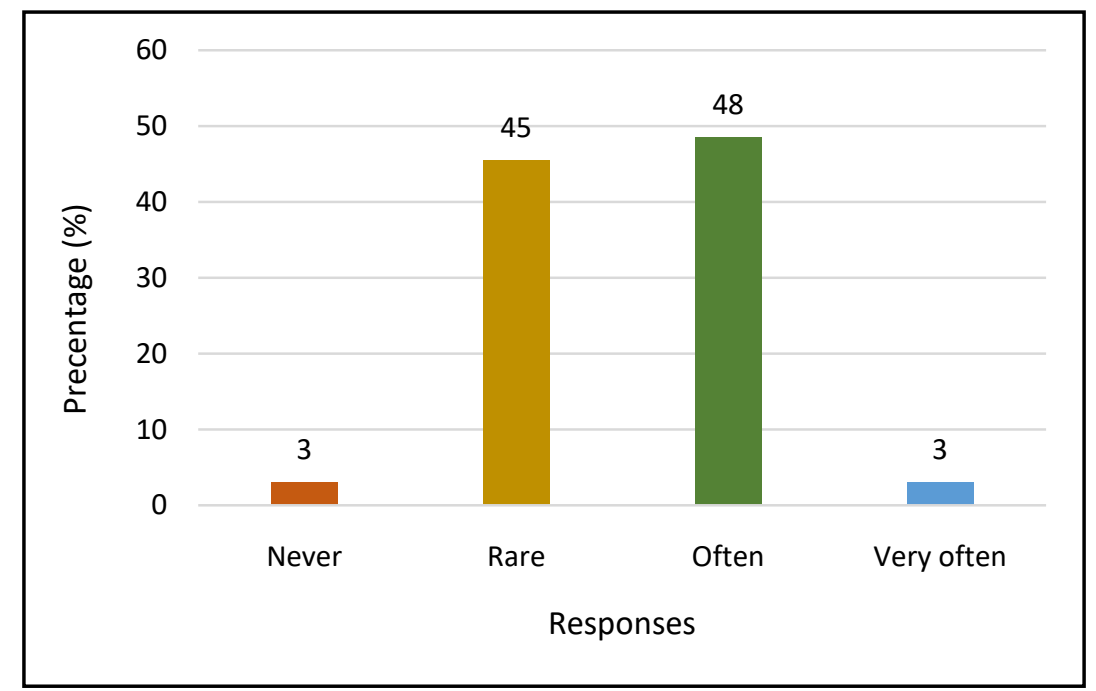

Figure 1 - Fishermen's responses towards the frequency of socialization of the Cantrang prohibition policy

Besides the socialization of Cantrang prohibition policy, it is equally important to socialize the importance of preserving demersal fish resources which are the fish target of Cantrang fishing. According to the regulation of the Ministry of Marine Affairs and Fisheries Number: 50 / PERMEN-KP / 2017 concerning Potential Estimation, Permitted Catch Amount, and Fish Resources Utilization Level in the State Management Area of Republic of Indonesia, the demersal fish utilization rate in Fisheries Management Area of Republic of the Indonesia (WPP-RI) 712 is fully exploited. Responses from Cantrang fishermen show that socialization of the importance of preserving demersal fish resources is done frequently (Figure 2).

Bias indicator is used to assess whether the assistance provided is appropriate and does not experience deviations. In the Cantrang prohibition policy, the alternatives provided by the central government as assistance in the realization of the policy are the provision of fishing gear replacement for vessels under 10 Gross Tonnage (GT), the provision of People's Business Credit (KUR) for vessels over $10 \mathrm{GT}$ to $30 \mathrm{GT}$, and the transfer of fishing areas to the Fishing Management Area of the Republic of Indonesia (WPP-RI) 718 as more potential area (Kementerian Kelautan and Perikanan Indonesia (KKP), 2017). 


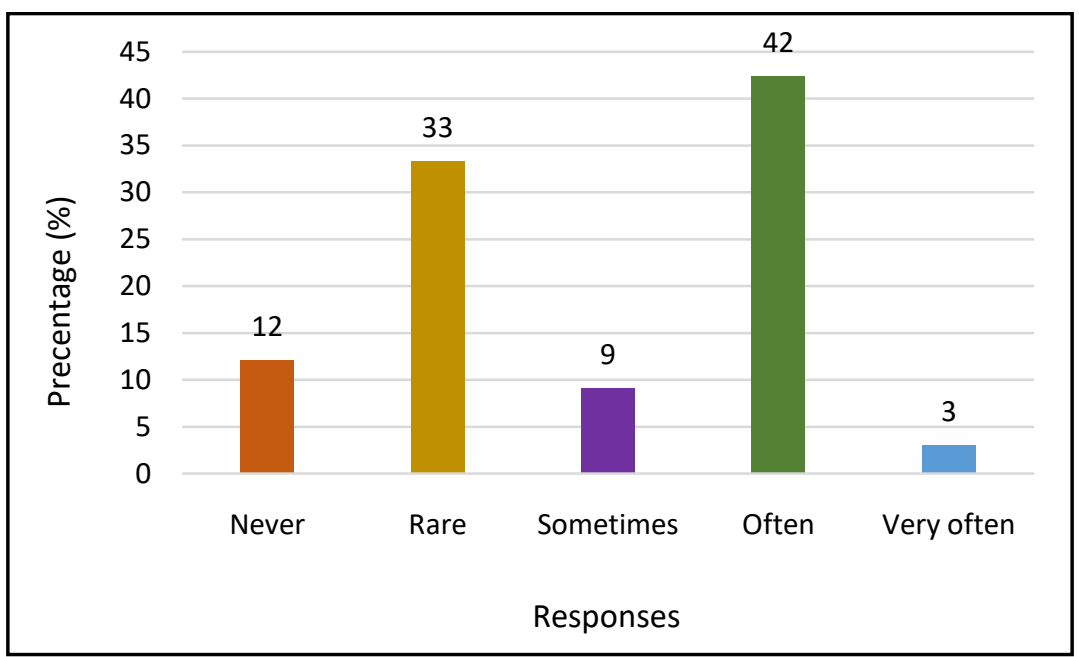

Figure 2 - Fishermen's responses to the socialization of the importance of preserving demersal fish resources

The response of $76 \%$ of Cantrang fishermen indicated that no assistance was received in Batang Regency, either new fishing gear to replace Cantrang or financial capital's business assistance, while $21 \%$ of fishermen stated that the government provided assistance oceanic gillnet for Cantrang replacement fishing gear (Figure 3).

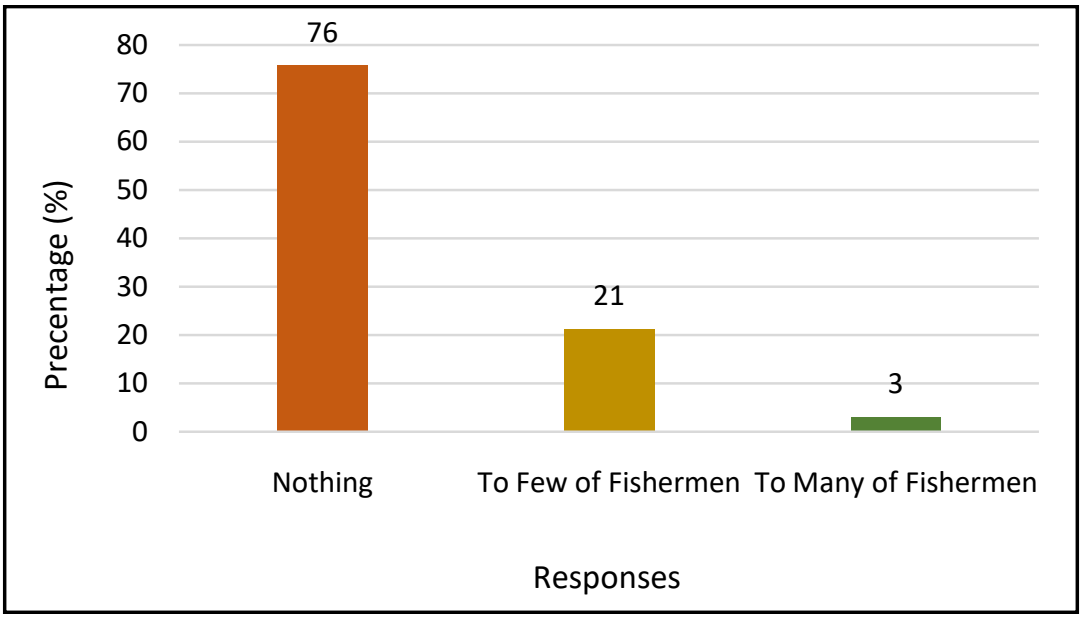

Figure 3 - Fishermen's responses to the implementation of alternative assistances provided by the government in the Cantrang prohibition policy

Program suitability of needs indicator is used to assess whether the assistance provided by the government is considered appropriate for fishermen and fulfil what fishermen needs. The gillnet oceanic fishing gear as an assistance for Cantrang replacement is considered unsuitable for use in Fishing Management Area of the Republic of Indonesia (WPP-RI) 712 as Cantrang fishing area where fishermen suffer losses with decreased income. In addition, the majority of Cantrang vessels in Batang Regency are 20-30 GT, where the assistance provided should be KUR instead of fishing gear replacement. Responses from $82 \%$ fishermen indicated that the assistance provided by the government is unsuitable with their needs (Figure 4).

Policy Outcomes. The policy impact is the form of changes in social and economic conditions to the policy target as a result of the policy output. The result can be the capability of rising new patterns of behavior or otherwise, it is unable to create new patterns of behavior towards the target group (Tahlea et al., 2015). Policy Outcomes indicators are used to monitor the effectiveness of policies and as a reminder to policy makers, whether the policies 
have been well designed and are objective in achieving the initial objectives of the policy. Policy outcomes are strongly influenced by policy outputs performance (Schuman, 2016).

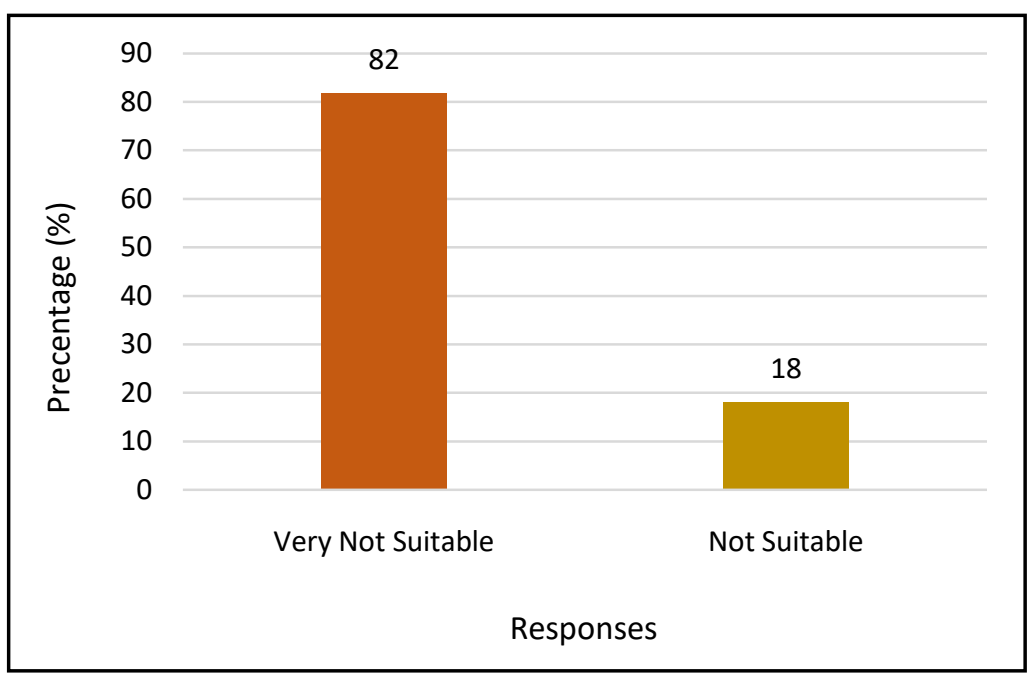

Figure 4 - Fishermen's responses to the suitability of alternative assistances provided by the government

Initial outcomes indicator is the initial impact that expected to occur on Cantrang fishermen after the Cantrang prohibition policy is issued. The initial impact expected is the termination of Cantrang use in Batang Regency followed by an alternative assistance issued by the Ministry of Marine Affairs and Fisheries (KKP) which is appropriate and suitable for fishermen. Based on the result (Figure 4), fishermen as policy targets stated that initial outcomes were not achieved because the alternative assistance carried out by the government towards fishermen were deemed inappropriate. This is caused by the fishing gear replacement is not able to generate the same income as Cantrang and it has decreased drastically. In addition, the absence of People Business Credit (KUR) alternative as capital assistance to replace fishing gear cause a high reluctance for fishermen to change their fishing gear.

Intermediate outcomes indicator is the expected medium term impact, where there is a change in Cantrang fishermen's mindset and perception towards the importance of using environmentally friendly fishing gear. Cantrang has been heavily modified by fishermen to increase their catching rate and has been included in the mini trawl fishing gear category, which trawl has been prohibited by regulation of Presidential Decree (KEPPRES) Number: 39 / KEPPRES / 1980 concerning Elimination of Trawl Nets. This makes Cantrang is considered as non-environmentally friendly fishing gear for catching unselected fish size include juveniles and damaging the water substrate which will disrupt the benthic ecosystem. Cantrang fishing also increases conflict between Cantrang fishermen and others fishermen, such as gill nets, trammel nets, hooks and lines because the decrease in the average Cantrang production of 9,222,166 kg will increase the production of other fishing gear to an average of $34,122,514 \mathrm{~kg}$, thus lead those fishermen support the Cantrang prohibition policy implementation (Hanafi et al., 2019; Wijayanto et al., 2019; Wijayanto et al., 2020). The importance of using environmentally friendly fishing gear is carried out in order to maintain the sustainability of fish resources, especially demersal fish. This cannot be done if fishermen do not have strong perception of the importance of the sustainability fisheries resources concept. Based on the results, the intermediate outcomes indicator has not been achieved. This is indicated by the very low level of perception and most of fishermen believe that demersal fish potential is not influenced by the rate of fishing but by the fortune from God.

Long-term outcomes indicator is the long term impact that is most related to the initial purpose of the form of the Cantrang prohibition policy. The essential purpose of the Cantrang prohibition policy were to maintain the sustainability of demersal fish resources, conserve 
coral reefs and stop illegal fishing activities with fishing gear that threatens sustainability itself. After the Cantrang prohibition policy was issued in 2015, instead of decrease, the fish production of the main catch commodities of the Cantrang continued to increase (Figure 5).

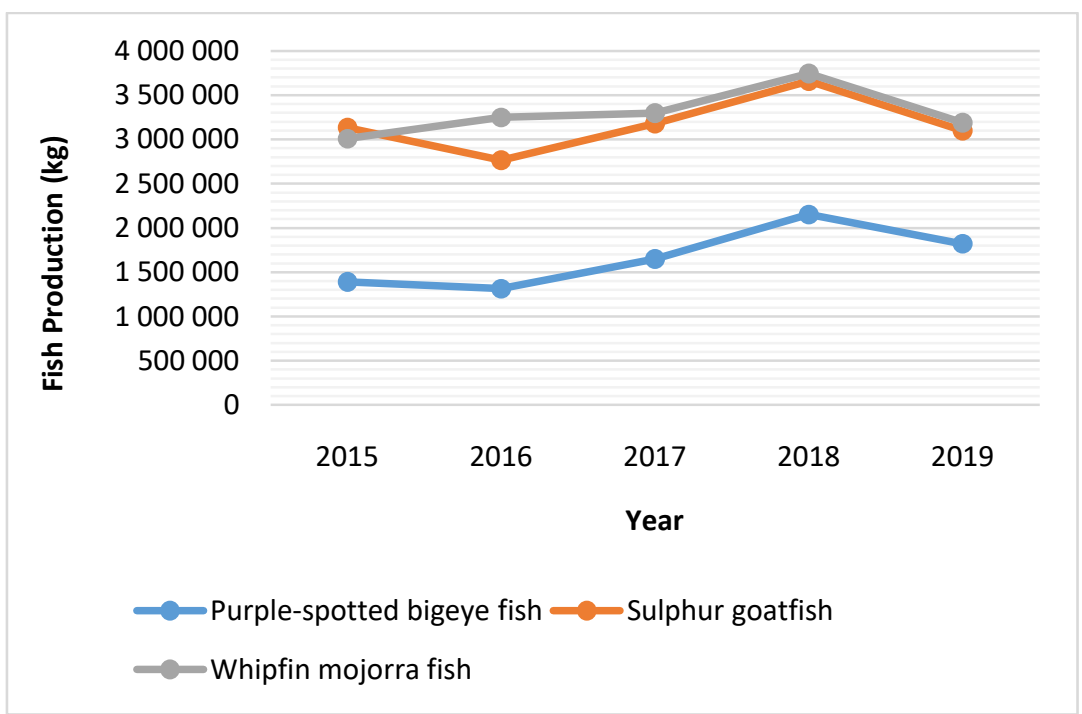

Figure 5 - The main catch commodities production of Cantrang in Batang Regency

(Source: PPP Klidang Lor annual report, 2020)

The fishing catch rate is used as an index of stock abundance, where a high rate means a high stock density. The catch rate is used as the basis for calculating stock density, standing stock and potential yield or Maximum Sustainable Yield (MSY) (Badrudin et al., 2011). According to the results of the study, demersal fish resources has been degraded with depleted status and a decrease in the sustainable potential with an overfishing status (Sumiono et al., 2002; Badrudin et al., 2011; Atmaja \& Duto, 2012). The level of fishing exploitation in the North Coast of Java as the fishing ground of Cantrang fishing has exceeded the recommended MSY limit (Hanafi et al., 2019). With the condition of demersal fish resources that continues to decline and the production of fishing catches continue to increase, it can be said that the long-term outcomes indicator in the Cantrang prohibition policy implementation has not been achieved.

Factors that affecting policy implementation. The policy format according to Goggin et al., (1990) consists of policy clarity, policy consistency and receipt of the policy message. Policy consistency is a basic aspect of policy implementation (Rachman, 2014). In the Cantrang prohibition policy, the government has been indecisive. Inconsistencies in the Cantrang prohibition policy implementation shown by the issuance of a discretion by the Minister of Maritime Affairs and Fisheries in 2018 which gave permission for Cantrang fishermen from Central Java Province, including Batang Regency, for still using Cantrang as fishing gear. This is due to unequal assistance received by fishermen for replacing Cantrang fishing gear, which only reaches $35 \%$ of the total number of Cantrang in Central Java Province. In addition, Cantrang vessels used to be prohibited from operating in the North Natuna Sea, but permits were given to 30 vessels to deal with foreign vessels invading these waters on the condition that the vessels have a Marine Certificate (SKM). SKM is a permit for Cantrang vessels over $30 \mathrm{GT}$, where for other fishing gear use a Fishing License (SIPI). The issuance of the SKM itself is considered not supporting the Cantrang prohibition policy implementation to strictly prohibit Cantrang as fishing gear, even though the issuance of SKM is accompanied by a requirement for vessels to install a Vessel Monitoring System (VMS) and pay Fishery Product Tax (PHP) as an installment to replace Cantrang fishing gear at a later date. The government's decision regarding whether Cantrang is fully prohibited or permitted under certain conditions has not met an agreement until now, thus hindering its policy implementation. 
According to Edward III (1980), the resources factor in policy implementation includes adequate human resources of policy implementers and financial supports. Without adequate resources, the implementation of the Cantrang prohibition policy will not run well even though it has been supported by good policy dissemination (Putra \& Khaidir, 2019). Resources factors in implementing the Cantrang prohibition policy include KUR assistance as a capital for Cantrang vessels size 20 GT-30 GT to replace Cantrang with environmentally fishing gear. The distribution of KUR which is called Perikanan Rakyat Credit has been realized since 2015 as much as Rp. 201.2 billion to six provinces including Central Java Province. The distributed KUR has an interest rate of $7 \%$ in 2018 by involving Indonesian government banks. However, the realization of Perikanan Rakyat Credit only ran for $17 \%$ of debtors in January to February in period 2019. This indicates that even though the government has made efforts to equalize the provision of KUR to fishery business operators, the KUR assistance program is running slowly. In addition, the scheme for the provision of Perikanan Rakyat Credit has not yet matured until 2019 has become an obstacle in realizing the alternative assistance on the Cantrang prohibition offered by the government.

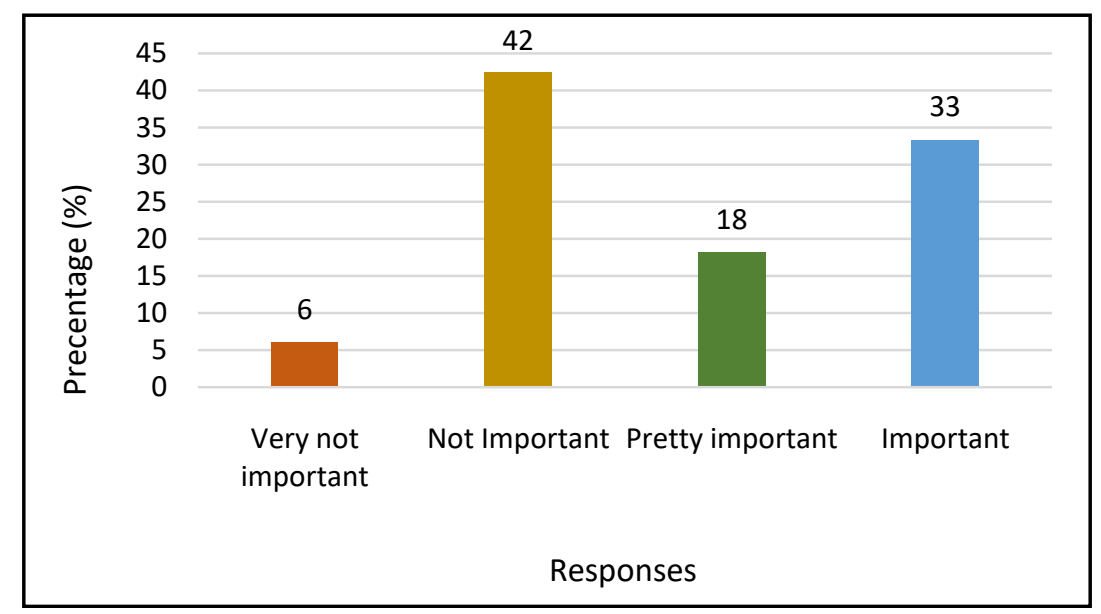

Figure 6 - Fishermen's responses to the importance of using environmentally friendly fishing gear

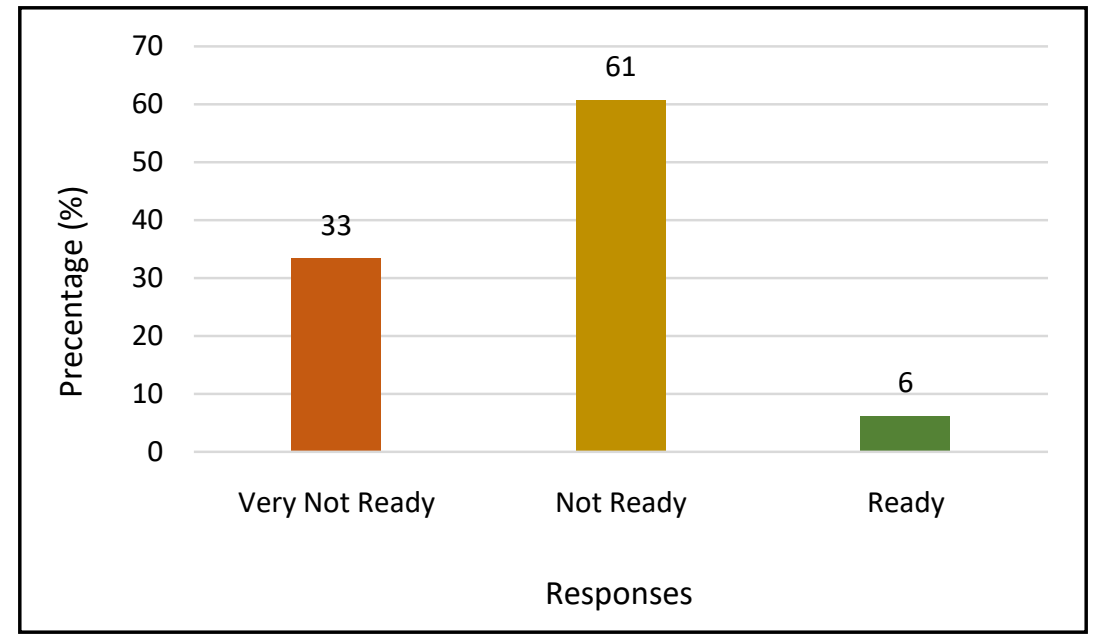

Figure 7 - Fishermen's responses to the willingness to use other fishing gear instead of Cantrang

The disposition or attitude of policy implementers and fishermen as policy targets are the most important factors in policy implementation as tendencies and behavior. According to Edward III (1980), tendencies and behavior means the willingness, desire and tendency of policy makers to implement policies properly to meet policy objectives (Mubarok et al., 2020). The attitude of the government as the policy implementers is not ready to implement optimally, which is indicated by the unachieved indicators of policy outputs. In addition, the 
government's attitude tends to be inconsistent, there is no synergy between various government parties and provides unsuitable alternative assistance for fishermen. Meanwhile, the attitude of fishermen as policy targets is uncooperative, indicated by the low level of awareness to use environmentally friendly fishing gear (Figure 6). Response from $33 \%$ of fishermen stated that it is important to use environmentally friendly fishing gear if it is able to provide the same amount of income as Cantrang's. In short, fishermen are reluctant to change fishing gear from Cantrang to other (Figure 7).

\section{DISCUSSION OF RESULTS}

Cantrang prohibition policy as issued in the regulation of the Ministry of Marine Affairs and Fisheries Number: 2 / PERMEN-KP / 2015 is one of the public policies in Indonesia. Public policy is the government's intentions to achieve certain goals with certain actions (Anyebe, 2018). Public policy is not only formed through government's intentions, but also through the ideology, interests and needs of various related parties both formally (the Executive, Legislative or the Judiciary branches, and political parties) and informally (civil society). Public policy formation is influenced by three important variables, which are ideas, media and public opinion (Almeida \& Gomes, 2018). Public policy should not only government intends to achieve certain goals, but also the formation of public policies must be accompanied by adjustments to the actual conditions of human and financial resources and pay attention to the problems and needs of the community with action as a solution (Anyebe, 2018). An action in realizing public policy is one of the stages of public policy and can be known as policy implementation.

Policy implementation is interpreted as implementing a policy decision into an action. Failure to implement policies is interpreted as a lack of political will or depicting weak institutions. Studies on policy implementation are important, especially in Asian and African countries (Mugambwa et al., 2018). It is important for the implementation of the Cantrang prohibition policy to include social and political analysis of fishermen as a measure of sensitivity and acceptance of the policies that have been formulated (Hanzl et al., 2001).

The implementation of the Cantrang prohibition policy is inseparable from the extent to which the Code of Conduct Responsible Fisheries (CCRF) has been implemented in an area, especially in Batang Regency. The use of environmentally fishing gear has been regulated in the CCRF as a standard and principle used internationally in supporting sustainable fisheries. The aim of CCRF is to maintain the condition at certain level and suppress the overexploitation of fisheries resources. There are 9 criteria for environmentally friendly fishing gear based on CCRF including selectivity, easy operation, safe for fishermen, capable of producing high quality catches, the operation does not damage the habitat, low bycatch, low biodiversity effect, does not capture protected biota, and is socially acceptable. The use of different fishing gear will significantly affect the environment and socio-economic impacts (Hanafi et al., 2019). Compared to gill net, hand line, lift net, purse seine and pot fish, Cantrang has the lowest selectivity value, has a high impact on biodiversity, captures a lot of bycatch, and the operation that uses axle when vessel being pulled can possibly endangers fishermen which can lead to permanent injuries. The Cantrang prohibition policy implementation is inseparable from the extent to which the CCRF has been implemented in an area, particularly in Batang Regency. The problem of non-environmentally friendly fishing gear is not only caused by Cantrang, but by ghost fishing by gillnets, capture of dolphins by purse seines, and explosive and poison fishing gear (Boopendranath, 2010). The Cantrang operation in overfishing fishing grounds only add the problems in implementing environmentally fishing gear in Indonesia's fisheries resources management efforts.

The policy format is influenced by policy inconsistencies that relax not being strict towards the violation of using Cantrang as fishing gear. The government is the main actor in the development and implementation of a policy (Jacob et al., 2019). Inconsistent policies will be a threat to the socio-political conditions of the country. Policy inconsistencies are a serious matter that needs to be investigated intellectually to find the cause (Nura \& Tabiu, 2014). 
The disposition factor ot the attitude and tendency of fishermen to use environmentally fishing gear is the main problem that hinders the successful implementation of the Cantrang prohibition policy. The high level of reluctance was caused by Cantrang has been used for generations and the fishermen did not have a side job. This indicates the minimum support for policy implementers to implement the policy. The attitude of policy implementers is one of the main factors that determine the level of policy effectiveness (Reza et al., 2019). Likewise, if policy implementers have different characters from policy makers, policy implementation will be ineffective (Putra \& Khaidir, 2019). The effectiveness and efficiency of the policy implementation is not only based on the implementer's ability to implement policies but also the willingness of policy targets in implementing policies (Mubarok et al., 2020).

The resource factor has constraints in the form of the absence of a clear KUR application scheme which is the reason for the obstruction of the implementation of the Cantrang prohibition policy (Handayani \& Lituhayu, 2020). According to Nadjib (2016), the capital aspect for capture fisheries business still faces many obstacles. The KUR policy has been issued in the Minister of Finance Regulation Number 135 of 2008 concerning the People's Business Credit Guarantee Facility, where in the regulation capital investment is given to fishermen with $70 \%$ capital from the government and $30 \%$ capital from the state banks. In applying for business credit, the bank still follows the general credit pattern, which are the collateral used are the vessel or fishing gear as the largest and permanent business assets. Meanwhile, the vessel or fishing gear used for daily operational needs, thus cannot be used as collateral for capital loans. This is exacerbated by the reluctance of formal financial institutions to provide business credit to fishermen due to various factors, which are uncertain fishermen's income, low commitment of fishermen to repay loans and the possibility of fishermen moving their fishing grounds without notification which can increase the difficulty to trace their whereabouts, thereby increasing bad credit risk opportunity. Meanwhile, from the fishermen side, they are also reluctant to apply for the business credit because of the difficulties of bureaucratic procedures and collateral requirements. The failure of the capture fisheries business banking credit scheme is caused by the scheme model for fishermen being equated with the scheme model for farmers who have regular income. Capital assistance for fishermen is very important, especially as the assistance of the Cantrang prohibition policy, considering that it takes a lot of capital to replace fishing gear into the new one.

\section{CONCLUSION}

The Cantrang prohibition policy has been violated by fishermen in Batang Regency, which can be said the policy has failed to be implemented. This is shown from all of policy outputs indicators and all policy outcomes that have not been achieved. The policy objective in restoring the condition of demersal fish resources in Indonesia cannot be achieved if the government has not been able to act decisively and facilitate alternative assistances according to the needs of fishermen. Factors that cause failure of policy implementation are inconsistency of policy format, disposition or attitude and tendency of fishermen that are not being supportive and low level perception towards sustainable fisheries concept, and the absence of financial support in fishing gear replacement.

\section{REFERENCES}

1. Ali, S. S., Krishnan, M., Jayasankar, J., Landge, A., Shenoy, L. (2014). Evaluation of Compliance of Marine Fisheries of Kerala with Article 8 of FAO CCRF. Fishery Technology, 51, 167-172.

2. Arisandi. (2016) Inkonsistensi Kebijakan Penggunaan Jaring Trawl. Jurnal Kebijakan and Manajemen Publik (JKMP), 4(1), 1-18.

3. Artati S.U.I. (2018). Regulasi Larangan Penggunaan Cantrang Untuk Penangkapan Ikan Bagi Nelayan Kecil. Jurnal Hukum Pidana and Pembangunan Hukum, 1(1). 
4. Badrudin, Aisyah, \& Ernawati T. (2011). Kelimpahan Stok Sumber Daya Ikan Demersal di Perairan Sub Area Laut Jawa. Jurnal Penelitian Perikanan Indonesia, 17(1), 11-21.

5. Boopendranath, M. R. (2010). Proceedings of the National Seminar on Future of Indian Fisheries: Emerging Policy Paradigms. Thiruvananthapuram: Department of Aquatic Biology \& Fisheries, University of Kerala.

6. Boopendranath, M. R (2012). Chapter 11: Fish Harvesting Systems for Resource Conversation. Cochin: Central Institute of Fisheries Technology.

7. Cole, M., Partson, G. (2006). Unlocking Public Value: A New Model for Achieving High Performance in Public Service Organizations. New Jersey: John Wiley \& Sons, Inc.

8. Edward III, G. C. (1980). Implementing Public Policy. Washington DC: Congressional Quarterly Press.

9. Ernawati, N., Zuliyati. (2015). Dampak Sosial and Ekonomi Atas Peraturan Menteri Kelautan and Perikanan Nomor 2/PERMEN-KP/2015 (Studi Kasus Kecamatan Juwana Kabupaten Pati. Prosiding Seminar Nasional Multi Disiplin Ilmu \& Call for Papers Unisbank (Sendi_UI). Universitas Muria Kudus, Kudus, pp. 1-10.

10. Goggin, M. L., Bowman, A., Lester, J., \& O'Toole, L. (1990). London: Implementation Theory and Practice: Toward a Third Generation. London: Scott, Foresman and Company.

11. Hadi, T. A., Abrar, M., Giyanto, Prayudha, B., Johan, O., Budiyanto, A., Dzumalek, A. R., Alifatri, L. O., Sulha, S., \& Suharsono. (2019). The Status of Indonesian Coral Reefs. Jakarta: Research Center for Oceanography (RCO).

12. Hanafi, A., Riniwati, H., \& Afandhi, A. (2019). Fishing Gears Assessment Based on Code of Conduct for Responsible Fisheries (CCRF) at Probolinggo. Journal of Environment and Sustainable Development, 10(2), 107-114.

13. Handayani, Z. S., \& Lituhayu D. (2020). Implementasi Kebijakan Larangan Alat Tangkap Cantrang di Kabupaten Pati. Journal of Public Policy and Management Review, 9(1), 1427.

14. Hanzl, S., Meschik, M., \& Sammer, G. (2001). Policy Formulation and Implementation. Brusselss: EU-funded Urban Transportation Research Project Results.

15. Herdiana, D. (2018). Sosialisasi Kebijakan Publik: Pengertian and Konsep Dasar. Jurnal IImiah Wawasan Insan Akademik, 1(3), 13-26.

16. Jacob, K., King, P., Mangalagiu, D., \& Rodriguez-Labajos, B. (2019). Global Environtment Outlook 6: Healthy Planet, Healthy People. Cambridge: Cambridge University Press.

17. Kartika, V. (2017). Kajian Dampak Penggunaan Cantrang sebagai Upaya Pengelolaan Sumber Daya Perikanan Berkelanjutan. Gema Keadilan, 4(1), 58-72.

18. Kementerian Kelautan and Perikanan Indonesia, 2017 Retrivied February 14, 2021, from https://kkp.go.id/artikel/1236-faq-kebijakan-pelarangan-cantrang.

19. Ma'mun, A., Priatna, A., Suwarso, \& Natsir, M. 2018 Potensi Distribusi Spasial Ikan Demersal di Laut Jawa (WPP NRI-712) dengan Menggunakan Teknologi Hidroakustik. Jurnal Ilmu and Teknologi Kelautan Tropis, 10(2), 489-500.

20. Mahmud. (2011). Metode Penelitian Pendidikan. Bandung: Pustaka Setia.

21. Mayu, D. H., Kurniawan, \& Febrianto A. (2018). Analisis Potensi and Tingkat Pemanfaatan Sumberdaya Ikan di Perairan Kabupaten Bangka Selatan. Jurnal Perikanan Tangkap, 2(1), 30-41.

22. Mubarok, S., Zauhar, S., Setyowati, E., \& Suryadi. (2020). Policy Implementation Analysis: Exploration of George Edward III, Marilee S Grindle, and Mazmanian and Sabatier Theories in the Policy Analysis Triangle Framework. Journal of Public Administration Studies, 5(1), 33-38.

23. Mugambwa, J., Nabeta, N., Rudaheranwa, N., Kaberuka, W., \& Munene J. C. (2018). Policy Implementation: Conceptual Foundations, Accumulated Wisdom and New Directions. Journal of Public Administration and Governance, 8(3), 211-232.

24. Nadjib, M. (2016). Peran Lembaga Keuangan Perdesaan dalam Pembiayaan Usaha Perikanan Tangkap. Jakarta: LIPI Press. 
25. Narmawi H., Martini M., 1994 Penelitian Terapan. Yogyakarta: Gajah Mada University Press.

26. Nura, A. A., \& Tabiu A. (2014). Counting the Cost of Policy Inconsistency in Nigeria: The Case of Privatization Policy. Public Policy and Administration Research, 3(4), 30-34.

27. Peraturan Menteri Kelautan and Perikanan (PERMEN-KP) Nomor 2 Tahun 2015 tentang Larangan Penggunaan Trawls and Seine Nets di Wilayah Pengelolaan Perikanan Republik Indonesia.

28. Peraturan Menteri Kelautan and Perikanan (PERMEN-KP) Nomor 50 Tahun 2017 tentang Estimasi Potensi, Jumlah Tangkapan yang Diperbolehkan and Tingkat Pemanfaatan Sumber Daya Ikan di Wilayah Pengelolaan Republik Indonesia.

29. Peraturan Menteri Keuangan Nomor 135 Tahun 2008 tentang Fasilitas Penjaminan Kredit Usaha Rakyat.

30. Poister, T. H. (2003). Measuring Performance in Public and Nonprofit Organizations. San Fransisco: Jossey-Bass.

31. Purwangka, F., Mubarok, H. A., \& Furqan. (2018). Komposisi Ikan Hasil Tangkapan Menggunakan Cantrang di Selat Madura. Jurnal Albacore, 2(2), 239-252.

32. Purwanto, E. A., \& Sulistyastuti, D. R. (2012). Implementasi Kebijakan Publik: Konsep and Aplikasinya di Indonesia. Yogyakarta: Gava Media.

33. Putra, R. H., \& Khaidir, A. (2019). Concept of George C. Edwards III on Implementation of Regional Regulations No. 12 of 2017 Concerning Youth in Granting Youth Service in West Sumatera. International Journal of Progressive Sciences and Technologies (IJPSAT), 15(1), 236-242.

34. Rachman, N. A. (2014). Pengukuran Kinerja Implementasi Kebijakan Penanggulangan Kemiskinan di Desa Wisata Brayut. Jurnal Kebijakan \& Administrasi Publik (JKMP), 18(2), 147-160.

35. Reza, K., Rianto, B., Subianto, A. (2019). Implementation of Regulation Policy \#58 (Permen-KP, 2014) of Ministry of Marine Affairs and Fisheries of Republic of Indonesia in Bitung City of North Sulawesi Province. Russian Journal of Agricultural and SocioEconomic Science (RJOAS), 1(85), 452-462.

36. Ripley, R. B., 1985 Policy Analysis in Political Science. Chicago: Nellson-Hall Inc.

37. Salim, A., \& Suwardi. (2016). Pengoperasian Jaring Cantrang Dalam Uji Coba Mata Jaring Bujur Sangkar (Square Mesh Panel) pada Kantong. Bulletin Teknik Litkayasa Sumber Daya and Penangkapan, 12(1), 61-70.

38. Sasmita, S., Martasuganda, S., \& Purbayanto A. (2013). Model Engineering for Testing the Design and Construction of Cantrang North Coast of Java. Marine Fisheries, 4(1), 5157.

39. Schuman, A. (2016). Using Outcome Indicators to Improve Policies Methods, Design Strategies and Implementation. OECD Regional Development Working Papers www.oecd.org/gov/regional/workingpapers.

40. Sugiyono. (2017). Metode Penelitian Kuantitatif, Kualitatif and R\&D. Bandung: Alfabeta.

41. Tahalea, S. N., Suwitri S., \& Rostyaningsih D. (2015). Evaluasi Dampak Kebijakan Penyelenggaraan Pelayanan Terpadu Satu Pintu di Badan Pelayanan Perizinan Terpadu Kota Semarang. Journal of Public Policy and Management Review, 4(3), 1-12.

42. Undang-Undang Nomor 45 Tahun 2019 tentang Perikanan.

43. Wijayanto, D., Setiyanto, I., Setyawan, H. A. (2019). Financial Analysis of the Danih Seine Fisheries Business in Rembang Regency, Indonesia. AACL Bioflux, 12(5), 18231831.

44. Wijayanto, D., Bambang, A. N., Kurohman, F. (2020). The Impact of Demersal Danish Seine Prohibition on Marine Fisheries Production in Pemalang Regency, Indonesia. AACL Bioflux, 13(4), 2320-2326. 